\title{
Immune profiling in human breast cancer is predictive of 5- and 10-year survival.
}

\author{
Brendon Coventry ${ }^{1 *}$, Michael J Weightman ${ }^{1}$, John Bradley², John M Skinner ${ }^{3}$ \\ From 30th Annual Meeting and Associated Programs of the Society for Immunotherapy of Cancer (SITC 2015) \\ National Harbor, MD, USA. 4-8 November 2015
}

\section{Background}

Immunotherapy for breast cancer is now being seriously considered, despite past beliefs that this cancer type was non-immunogenic. Immune profiling has been variably associated with outcome, but standard techniques have greatly limited interpretation. These studies examine immune profiling of breast cancer patients using highsensitivity methods in relation to clinical outcome.

\section{Methods}

High-sensitivity detection and analysis methods were used to determine Immune Profiles of female human breast cancer in Tumour Infiltrating Leukocytes (TIL) in longitudinal cohort comparative outcome studies.

\section{Results}

Immune profiles showed predominantly CD3, CD4, CD45RO TIL with low/absent IL-2a receptor expression. However, these were significantly correlated to 5- and 10 -year survival times.

\section{Conclusions}

Immune profiling of the TIL infiltrate in human breast carcinoma using high-sensitivity detection and analysis techniques showed predominance of CD3 cells, being ab-TCR, CD4 T cells of mainly memory phenotype. Importantly, these findings were strongly predictive of 5- and 10-year survival. This indicates the real possibility that TIL infiltration in breast cancer might be open to immunological manipulation therapeutically to improve clinical outcome.

\section{Authors' details \\ ${ }^{1}$ Discipline of Surgery, University of Adelaide \& Breast, Endocrine \& Surgical Oncology Unit, Royal Adelaide Hospital, Australia. ${ }^{2}$ Department of Clinical}

'Discipline of Surgery, University of Adelaide \& Breast, Endocrine \& Surgical Oncology Unit, Royal Adelaide Hospital, Australia

Full list of author information is available at the end of the article
Immunology, Flinders University, Flinders Medical Centre, Adelaide, Australia. ${ }^{3}$ Pathology, Flinders University, Flinders Medical Centre, Adelaide, Australia.

Published: 4 November 2015

doi:10.1186/2051-1426-3-S2-P131

Cite this article as: Coventry et al:: Immune profiling in human breast cancer is predictive of 5- and 10-year survival.. Journal for

ImmunoTherapy of Cancer 2015 3(Suppl 2):P131.
Submit your next manuscript to BioMed Central and take full advantage of:

- Convenient online submission

- Thorough peer review

- No space constraints or color figure charges

- Immediate publication on acceptance

- Inclusion in PubMed, CAS, Scopus and Google Scholar

- Research which is freely available for redistribution
() Biomed Central
C Biomed Central

(c) 2015 Coventry et al. This is an Open Access article distributed under the terms of the Creative Commons Attribution License (http:// creativecommons.org/licenses/by/4.0), which permits unrestricted use, distribution, and reproduction in any medium, provided the original work is properly cited. The Creative Commons Public Domain Dedication waiver (http://creativecommons.org/publicdomain/ zero/1.0/) applies to the data made available in this article, unless otherwise stated. 